\title{
Biodegradable Copolymers Obtained by Solution Polymerization
}

\author{
Katiusca Wessler Miranda ${ }^{a, b *}$, Eduarda Cani de Souza ${ }^{a}$, Michele Tomaz, \\ Marcia Adriana Tomaz, Duarte ${ }^{a}$ Sérgio Henrique Pezzin ${ }^{b}$
${ }^{a}$ Centro Universitário Tupy - UNISOCIESC, Rua Albano Schmidt, 3333, Boa Vista, Joinville, SC, Brazil
${ }^{b}$ Centro de Ciências Tecnológicas - CCT, Universidade do Estado de Santa Catarina - UDESC, Rua Paulo Malschitzki, s/n, Campus Prof. Avelino Marcante, Bairro Zona Industrial Norte, \\ Joinville, SC, Brazil
}

Received: December 11, 2014; Revised: August 30, 2015

\begin{abstract}
This study aims the synthesis of copolymers of poly (1-lactic acid) and polycaprolactone by ring opening polymerization. The reactions between 1-lactide (LLA) and $\varepsilon$-caprolactone (CL) monomers, in 100/0, 95/5, 90/10 and 80/20 LLA/CL mass ratios, were conducted in refluxing toluene, using Stannous octoate as iniciator, methanol as co-iniciator and inert atmosphere $\left(\mathrm{N}_{2}\right)$. The reaction medium was maintained under stirring at $120^{\circ} \mathrm{C}$ for 24 hours. The samples were characterized by carbon- 13 and proton nuclear magnetic resonance $\left(\mathrm{C}^{13}\right.$-NMR and $\mathrm{H}^{1}$-NMR), and gel permeation chromatography (GPC). Monomers were characterized by thermogravimetry (TG). Copolymers were formed only in samples containing $20 \mathrm{wt} \% \varepsilon$-caprolactone. NMR spectra of the other samples showed no evidence of CL units. This fact may be associated with the low-temperature volatilization of monomers. The GPC analysis showed that the increase of CL concentration decrease the molecular weight of copolymers.
\end{abstract}

Keywords: ring opening polymerization, copolymer, poly(l-lactide acid), polycaprolactone

\section{Introduction}

Various aliphatic polyesters, such as poly (lactic acid) (PLA) and poly ( $\varepsilon$-caprolactone) (PCL), have been of great interest due to their biocompatibility, biodegradability and mechanical strength ${ }^{1-5}$. PLA can be obtained from renewable resources, however, it is a brittle material which represents an important handicap for further applications in biomedical area, packaging, industrial and agricultural fields ${ }^{6}$. On the other hand, PCL is characterized by a relatively low glass transition temperature $\left(\sim 60^{\circ} \mathrm{C}\right)$; thus, at room temperature it behaves as a tough plastic ${ }^{7}$. PLA and PCL copolymers have been developed in order to take advantage of synergistic improvement in properties offered by both polymers ${ }^{8}$.

The PLLA and PCL can be obtained by ring-opening polymerization of L-lactide (LLA) and $\varepsilon$-caprolactone (CL), respectively, using Stannous octoate as the initiator and low molecular weight alcohols. The most used technique for that is mass polymerization, which employs only monomer and catalysts ${ }^{9,10}$.

The advantages of mass polymerization are the high polymer purity and the easy production. On the other hand, the reaction control becomes difficult due to the formation of hot spots during the synthesis, which causes heat dissipation problems. The solution polymerization technique can reduce this difficulty since a solvent is added to the reaction medium, despite the few papers developed in this area used toxic organic solvents ${ }^{11}$. However, when it is interesting to modify the properties of these polymers by adding nanoparticles in situ, the presence of a solvent can make the process easier.

*e-mail: katiusca.wessler@sociesc.org.br
In the last two decades, there is growing interest in the modification of the properties of PLLA, which is rigid and brittle, either by obtaining copolymers with other monomers to provide flexibility, or by adding nanoparticles to improve its tensile strength and lower its gas permeability ${ }^{12-14}$.

The objective of this study was to synthesize a copolymer of PLLA and PCL by solution polymerization, using toluene as solvent. Evidence of copolymer formation is discussed in terms of carbon and hydrogen nuclear magnetic resonance analysis, while the molar masses were evaluated by gel permeation chromatography.

\section{Material and Methods}

The monomers employed in this work were $\varepsilon$-caprolactone (CL) $97 \%$ (Sigma Aldrich) and the L-lactide (LLA) (Purac ${ }^{\circledR}$ ). The initiator stannous octoate, $\mathrm{Sn}(\mathrm{Oct})_{2}$, was purchased from Sigma Aldrich ${ }^{\circledR}$. Toluene and methanol, both in spectrophotometric grade, were obtained from Merck ${ }^{\circledR}$.

\subsection{Synthesis of PLLA and copolymers of PLLA-CO-PCL}

The synthesis of copolymers from L-lactide (LLA) and $\varepsilon$-caprolactone $(\mathrm{CL})$ was carried out in a three-necked bottom flask $(250 \mathrm{~mL})$ with the central neck adapted to a Graham condenser. The side necks were coupled to a thermometer (ETS IKA) connected to the heating plate with magnetic stirrer. The copolymerization was carried out in different feed ratios of LLA to CL (100/0, 95/5, 90/10, 85/15 and $80 / 20, \mathrm{w} / \mathrm{w})$. Sn $(\mathrm{Oct})_{2}$, toluene and methanol were added to 
monomers and maintained under dry nitrogen atmosphere at $120^{\circ} \mathrm{C}$ for 24 hours. The compositions of the reaction media is described in Table 1.

After 24 hours, the polymer solution was precipitated in cold methanol, the filtered solvent was removed. Then, the polymer was dried under vacuum.

\subsection{Characterization}

The samples of PLLA and PLLA-co-PCL were subjected to carbon-13 nuclear magnetic resonance analysis $\left({ }^{13} \mathrm{C}-\mathrm{NMR}\right)$ in a Varian Mercury Plus spectrometer operating at $500 \mathrm{MHz}$, $294 \mathrm{~K}$, for 1 hour. In addition, ${ }^{1} \mathrm{H}$ nuclear magnetic resonance $\left({ }^{1} \mathrm{H}-\mathrm{NMR}\right)$ was performed in a Bruker AC 200 at $294 \mathrm{~K}$. The solvent used was deuterated chloroform $\left(\mathrm{CDCl}_{3}\right)$, and tetramethylsilane (TMS) was used as an internal standard.

TG curves to l-lactide and $\varepsilon$-caprolactone were obtained in TA Q20 equipment, operating from 20 to $400{ }^{\circ} \mathrm{C}$, at $10{ }^{\circ} \mathrm{C} / \mathrm{min}$. The monomers samples were conditioned in a platinum sample holder and analyses were conducted under $\mathrm{N}_{2}$ atmosphere with a flow of $40 \mathrm{~mL} / \mathrm{min}$.

Gel Permeation Chromatography (GPC) was performed using Waters 1525-detector ELSD 2424, Styragel HR3ETHF and Styragel HR5RTHF $(4.6 \times 300 \mathrm{~mm})$ columns. All samples were dissolved in chloroform at a concentration of $1.0 \%$ $(\mathrm{w} / \mathrm{v})$ and analyzed at $40^{\circ} \mathrm{C}$. Chloroform was used as eluent (flow rate $=0.5 \mathrm{~mL} / \mathrm{min}$ ). Molecular weights $\left(M_{n}\right.$ and $\left.M_{w}\right)$ and polydispersity $\left(\mathrm{M}_{\mathrm{w}} / \mathrm{M}_{\mathrm{n}}\right)$ were determined with respect to the polystyrene standard.

\section{Results and Discussion}

Figure 1 shows the chemical reaction between the monomers of L-lactide and $\varepsilon$-caprolactone in order to obtain the copolymer of PLLA-co-PCL. The letters in the chemical structure of copolymer indicate potential signals emitted by carbons or hydrogens evidenced by $\mathrm{C}^{13}$-NMR and $\mathrm{H}^{1}$-NMR techniques, respectively.

Table 2 presents ${ }^{13} \mathrm{C}$-NMR signals achieved by different researchers in studying copolymers of PLLA-co-PCL by bulk polymerization technique ${ }^{10}$, copolymers of $\mathrm{PHB}$ and $\mathrm{PCL}^{15}$ and PLLA synthesis by direct condensation of lactic acid ${ }^{16}$, and in the synthesis of poly (L-D-L lactic acid) ${ }^{4}$.

The ${ }^{13} \mathrm{C}$-NMR spectra for samples $100 / 0,95 / 5,90 / 10$ and $85 / 15$ showed signals relating to the chemical structure of 1-lactide (LLA), with chemical shifts at $169 \mathrm{ppm}$ relative to the<smiles>CC1OC(=O)C(C)OC1=O</smiles><smiles>CCC(O)CC(=O)CCCCCCC(=O)OC(C)C(=O)OCCI</smiles>

Figure 1. Chemical structure of PLLA-co-PCL copolymer with carbons marked for identification by ${ }^{13} \mathrm{C}-\mathrm{NMR}$.

Table 1. Mass and molar composition of reaction media for the preparation of PLLA and its copolymers with PCL.

\begin{tabular}{|c|c|c|c|c|c|c|c|c|c|c|}
\hline \multirow{2}{*}{ Reagents } & \multicolumn{2}{|c|}{$100 / 0$} & \multicolumn{2}{|c|}{$95 / 05$} & \multicolumn{2}{|c|}{$90 / 10$} & \multicolumn{2}{|c|}{$85 / 15$} & \multicolumn{2}{|c|}{$80 / 20$} \\
\hline & m (g) & n (mol) & m (g) & n (mol) & m (g) & n (mol) & m (g) & n (mol) & m (g) & n (mol) \\
\hline LLA & 50.0 & 0.3472 & 47.5 & 0.3298 & 45.0 & 0.3125 & 42.5 & 0.2951 & 40.0 & 0.2777 \\
\hline$\varepsilon C L$ & - & - & 2.5 & 0.0219 & 5.0 & 0.0438 & 7.5 & 0.0657 & 10.0 & 0.0877 \\
\hline $\mathrm{CH}_{3} \mathrm{OH}$ & $7.8 \times 10^{-3}$ & $2.3 \times 10^{-4}$ & $7.8 \times 10^{-3}$ & $2.3 \times 10^{-4}$ & $7.8 \times 10^{-3}$ & $2.3 \times 10^{-4}$ & $7.8 \times 10^{-3}$ & $2.3 \times 10^{-4}$ & $7.8 \times 10^{-3}$ & $2.3 \times 10^{-4}$ \\
\hline $\mathrm{Sn}(\mathrm{Oct})_{2}$ & $7.3 \times 10^{-3}$ & $2.3 \times 10^{-4}$ & $7.3 \times 10^{-3}$ & $2.3 \times 10^{-4}$ & $7.3 \times 10^{-3}$ & $2.3 \times 10^{-4}$ & $7.3 \times 10^{-3}$ & $2.3 \times 10^{-4}$ & $7.3 \times 10^{-3}$ & $2.3 \times 10^{-4}$ \\
\hline $\mathrm{C}_{6} \mathrm{H}_{5} \mathrm{CH}_{3}$ & 43.3 & 0.4706 & 43.3 & 0.4706 & 43.3 & 43.3 & 43.3 & 0.4706 & 43.3 & 0.4706 \\
\hline
\end{tabular}

Table 2. Chemical shifts (ppm) from ${ }^{13} \mathrm{C}-\mathrm{NMR}$ spectra cited in literature and obtained experimentally

\begin{tabular}{|c|c|c|c|c|c|c|c|c|c|}
\hline \multirow[b]{2}{*}{ Signal } & \multicolumn{4}{|c|}{ Literature } & \multicolumn{5}{|c|}{ Experimental } \\
\hline & Castro $^{10}$ & Roa et al. ${ }^{15}$ & Chen et al. ${ }^{16}$ & $\begin{array}{c}\text { Motta \& } \\
\text { Duek }^{4}\end{array}$ & $100 / 0$ & $95 / 5$ & $90 / 10$ & $85 / 15$ & $80 / 20$ \\
\hline A & - & - & - & - & - & - & - & - & 16.75 \\
\hline B & 173.50 & 175 & - & - & - & - & - & - & 175.01 \\
\hline b1 & 169.60 & - & 169.53 & 166 and 169 & 169.6 & 169.6 & 169.6 & 169.60 & 169.59 \\
\hline $\mathrm{C}$ & 69.06 & - & 68.93 & 69 & 69.02 & 68.98 & 68.98 & 68.96 & 69.23 \\
\hline $\mathrm{c} 1$ & - & - & - & - & - & - & - & - & 69.02 \\
\hline $\mathrm{D}$ & 16 & - & 16.57 & 16.6 & 16.61 & 16.62 & 16.62 & 16.57 & 16.58 \\
\hline $\mathrm{e}$ & 64.14 & 65 & - & - & - & - & - & - & 62.46 \\
\hline $\mathrm{f}$ & 25 & 25 & - & - & - & - & - & - & 25.20 \\
\hline $\mathrm{g}$ & 24 & 24 & - & - & - & - & - & - & 24.56 \\
\hline $\mathrm{h}$ & 28 & 28 & - & - & - & - & - & - & 32.08 \\
\hline $\mathrm{i}$ & 33 & 34 & - & - & - & - & - & - & 33.93 \\
\hline
\end{tabular}


carbonyl carbon, at $68.9 \mathrm{ppm}$ related to tertiary carbon, and at $16.6 \mathrm{ppm}$ related to the methylene group -CH-. Chemical shifts of caprolactone unit (CL) were only presented in the 80/20 sample. In Figure 2 there is a comparison between the $C^{13}$-NMR spectra for samples of PLLA (100/0) and PLLA-co-PCL (80/20).

The areas of the ${ }^{13} \mathrm{C}-\mathrm{NMR}$ signals related to $\varepsilon-\mathrm{CL}-\mathrm{CH}_{2}$ groups (20.2 ppm) and the $-\mathrm{CH}_{3}$ groups of the LLA (16.2 ppm) were calculated, and the ratio between them expresses the percentage of $\varepsilon$-CL chemically bound to LLA, according to Equation 1.

$$
\begin{aligned}
& \% \varepsilon C L=\frac{\text { Integral da área do pico da } \varepsilon C L}{\text { Integral da área do pico do } L L A} x \\
& 100 \% \varepsilon C L=\frac{\text { IntegraleCL }}{\text { IntegralLLA }} .100
\end{aligned}
$$

It is observed that in the synthesis of the $85 / 15$ copolymer, only $2.7 \%$ of the final product consists of CL units, whereas in the synthesis of $80 / 20$ copolymer, $30.3 \%$ of the final product consists of CL units.

During solution polymerization, the temperature $\left(120^{\circ} \mathrm{C}\right)$ used for the synthesis is sufficient to volatilize the molecules of $\varepsilon$-caprolactone (CL) and L-lactide (LLA), which possibly has hindered the reactivity between the two monomers. Thermogravimetric analysis of monomers (Figure 3) showed that the starting temperature of mass loss $\left(\mathrm{T}_{\text {onset }}\right.$ ) is $64^{\circ} \mathrm{C}$ for $\mathrm{CL}$ and $104^{\circ} \mathrm{C}$ for the LLA, and the two monomers lose mass by volatilization. Even if the system is heated under reflux, monomers may remain in dynamic equilibrium, and as the temperature of volatilization of CL is lower, the gaseous state is richer in CL, decreasing the reactivity of this monomer.

Castro $^{10}$ studied random copolymers of poly(1-lactic acid) and polycaprolactone via mass polymerization without the addition of solvents. The researcher varied the L-lactide/ $\varepsilon$-caprolactone ratios, and observed by $\mathrm{C}^{13}-\mathrm{MNR}$ that the synthesis fed with less than $20 \mathrm{wt} \%$ of $\varepsilon$-caprolactone produced structures with $100 \%$ of poly(1-lactic acid). The author also used a temperature of $120^{\circ} \mathrm{C}$ and a closed vacuum system.

Some studies on the synthesis of aliphatic polyesters have been carried out in recent years and the NMR technique has been used to confirm the formation of polymers. The ${ }^{1} \mathrm{H}-\mathrm{NMR}$ signals for the pure PCL and PLLA based on these works are presented in Table 3.

Figure 4 shows the $\mathrm{H}^{1}$-MNR spectra of PLLA 100/0 samples. The $\mathrm{H}^{1}$-NMR spectra for samples with less than $20 \mathrm{wt} \%$ of CL showed only signals referring to the LLA units. For PLLA $(100 / 0)$, a major intensity doublet at 1.62 and $1.59 \mathrm{ppm}$ refers to the signals of methyl groups $\left(-\mathrm{CH}_{3}\right)$. Two doublets of lower intensity appeared at 1.54 and $1.53 \mathrm{ppm}$, and at 1.51 and $1.50 \mathrm{ppm}$, which can be assigned to methyl groups bonded to the terminal carbons. A quadruplet related to groups - $\left(\mathrm{CH}-\mathrm{CH}_{3}\right)$ appeared at 5.14, 5.17, 5.21 and 5.24 ppm. A second quadruplet assigned to terminal groups $-\left(\mathrm{CH}-\mathrm{CH}_{3}\right)$ was recorded at 4.34, 4.38, 4.41, $4.45 \mathrm{ppm}$.

Motta \& Duek ${ }^{4}$ studied the synthesis of PLLA using the same catalyst, but via mass polymerization. The researchers prepared polymers with molar ratio monomer/catalyst between 4,000 and 5,500, and obtained polymers with molecular

Table 3. Signals of ${ }^{1} \mathrm{H}-\mathrm{NMR}$ for PCL and PLLA, obtained from reactions of ring-opening using $\mathrm{Sn}(\mathrm{Oct})_{2}^{[2,15,17]}$.

\begin{tabular}{cccc}
\hline & PCL & Poly(lactide acid) \\
\hline Signal & Hydrogens & Signal & Hydrogens \\
\hline 2.64 & $-\mathrm{C}(\mathrm{O})-\mathrm{CH}_{2}-\mathrm{CH}_{2}-\mathrm{CH}_{2}-\mathrm{CH}_{2}-\mathrm{CH}_{2}-\mathrm{O}-$ & 1.6 & $-\mathrm{C}(\mathrm{O})-\mathrm{CH}(\mathbf{C H})-\mathrm{O}-\mathrm{C}(\mathrm{O})-\mathrm{CH}(\mathrm{CH})-\mathrm{O}-\mathrm{H}$ \\
1.77 & $-\mathrm{C}(\mathrm{O})-\mathrm{CH}_{2}-\mathbf{C H}_{2}-\mathrm{CH}_{2}-\mathrm{CH}_{2}-\mathrm{CH}_{2}-\mathrm{O}-$ & 1.5 & $-\mathrm{C}(\mathrm{O})-\mathrm{CH}(\mathrm{CH})-\mathrm{O}-\mathrm{C}(\mathrm{O})-\mathrm{CH}(\mathbf{C H})-\mathrm{O}-\mathrm{H}$ \\
1.86 & $-\mathrm{C}(\mathrm{O})-\mathrm{CH}_{2}-\mathrm{CH}_{2}-\mathbf{C H}_{2}-\mathrm{CH}_{2}-\mathrm{CH}_{2}-\mathrm{O}-$ & 5.1 & $-\mathrm{C}(\mathrm{O})-\mathbf{C H}(\mathrm{CH})-\mathrm{O}-\mathrm{C}(\mathrm{O})-\mathrm{CH}(\mathrm{CH})-\mathrm{O}-\mathrm{H}$ \\
1.77 & $-\mathrm{C}(\mathrm{O})-\mathrm{CH}_{2}-\mathrm{CH}_{2}-\mathrm{CH}_{2}-\mathbf{C H}_{2}-\mathrm{CH}_{2}-\mathrm{O}-$ & 4.4 & $-\mathrm{C}(\mathrm{O})-\mathrm{CH}(\mathrm{CH})-\mathrm{O}-\mathrm{C}(\mathrm{O})-\mathbf{C H}(\mathrm{CH})-\mathrm{O}-\mathrm{H}$ \\
4.43 & $-\mathrm{C}(\mathrm{O})-\mathrm{CH}_{2}-\mathrm{CH}_{2}-\mathrm{CH}_{2}-\mathrm{CH}_{2}-\mathbf{C H}_{2}-\mathrm{O}-$ & & \\
\hline
\end{tabular}

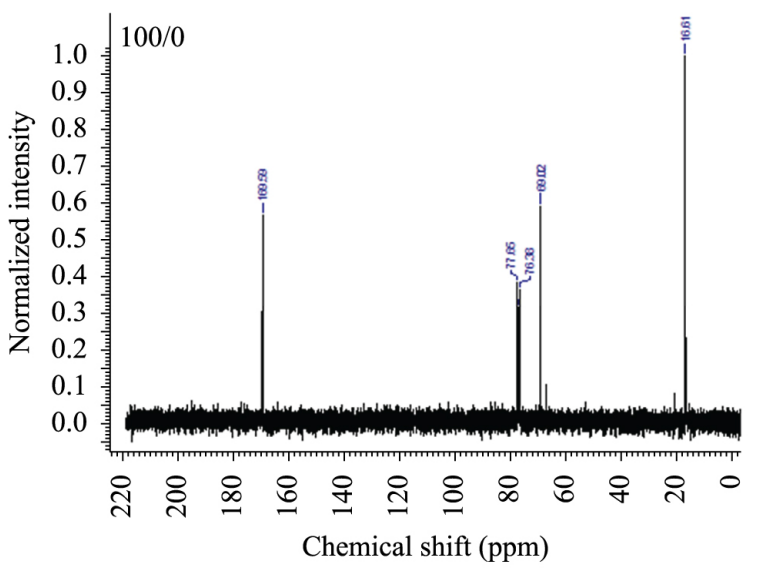

(a)

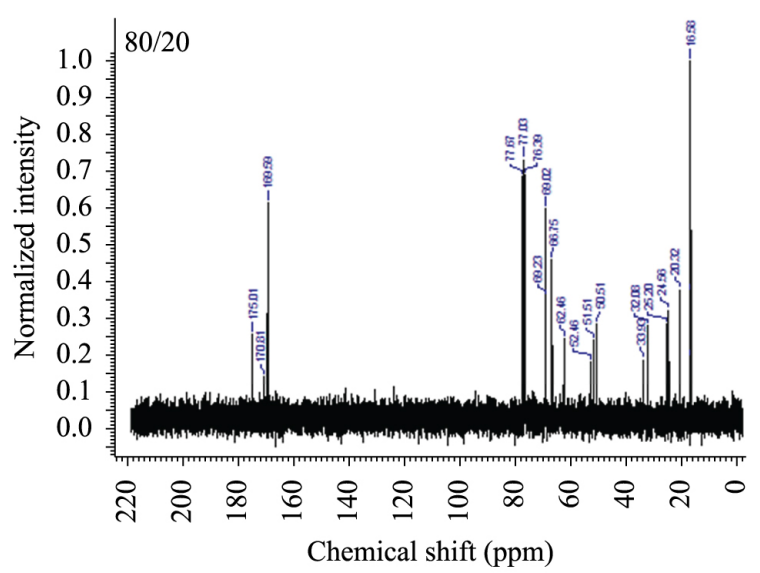

(b)

Figure 2. ${ }^{13} \mathrm{C}-\mathrm{NMR}$ spectra for samples of (a) PLLA (100/0) and (b) PLLA-co-PCL (80/20). 


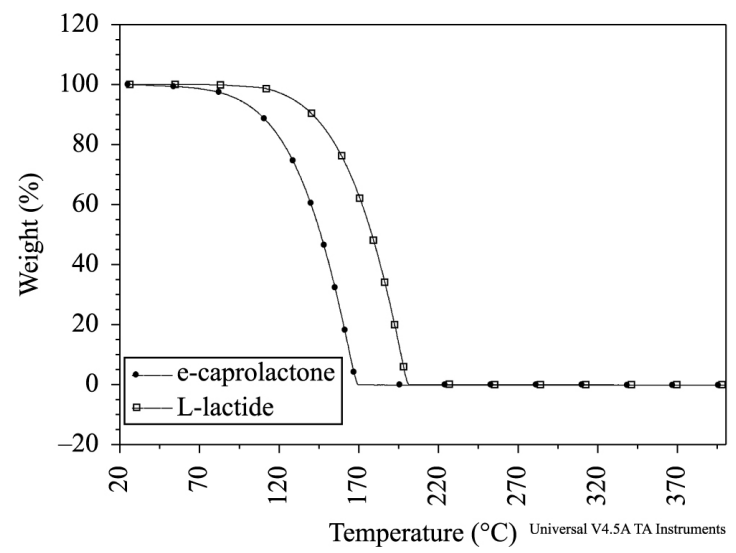

Figure 3. TG curves of LLA and CL monomers.

weights between 75,000 and $150,000 \mathrm{~g} / \mathrm{mol}$. The ${ }^{1} \mathrm{H}-\mathrm{NMR}$ spectra show chemical shifts $(\delta)$ at $5.15 \mathrm{ppm}$ for the $\mathrm{CH}$ groups and at $1.58 \mathrm{ppm}$ for $\mathrm{CH}_{3}$ groups, both singlet signals ${ }^{4}$.

The $95 / 5,90 / 10$ and $85 / 15$ samples showed similar spectra and none of them indicate any evidence of the presence of CL units. For the 85/15 sample (Figure 5), a major intensity doublet at 1.58 and $1.55 \mathrm{ppm}$ refers to groups $\left(-\mathrm{CH}_{3}\right)$ and another of lower intensity at 1.48 and $1.44 \mathrm{ppm}$ is assigned to terminal groups $\left(-\mathrm{CH}_{3}\right)$. Quadruplets were recorded at $5.10,5.13,5.17$ and $5.20 \mathrm{ppm}$, and at 4.05, 4.08, 4.12 and $4.15 \mathrm{ppm}$, corresponding to the groups $\left(-\mathrm{CH}-\mathrm{CH}_{3}\right)$ and terminals $\left(-\mathrm{CH}-\mathrm{CH}_{3}\right)$, respectively. All obtained data are in accordance to the literature ${ }^{2,4}$.

The 80/20 sample, however, presents several peaks such as singlet and duplets in the region between 1.71 and $1.45 \mathrm{ppm}$. The duplets at 1.57 and 1.56 , and at $1.49 \mathrm{ppm}$ and $1.48 \mathrm{ppm}$ can be assigned to the group $\left(-\mathrm{CH}_{3}\right)$ of LLA units, suggesting that copolymers with different sequences of two monomers can be obtained (Figure 6). The peaks of highest intensity at 1.53 and $1.16 \mathrm{ppm}$ can be assigned to methylene hydrogens $\left(-\mathrm{CH}_{2}-\right)$ bonded to the $\beta$ carbon and to the $\gamma$ carbon of $\mathrm{CL}$ unit, respectively. A peak around $2.34 \mathrm{ppm}$ can be assigned to $\alpha$ methylene hydrogens of CL unit. The peak related to hydrogens bonded to the $\delta$ carbon of CL units arises at $4.96 \mathrm{ppm}$. Two quadruplets between 5.13 and $5.25 \mathrm{ppm}$ refer to the hydrogens of the groups $\left(-\mathrm{CH}-\mathrm{CH}_{3}\right)$ of LLA units. Once again, the signal split can indicate two different configurations for the copolymer of PLLA-CO-PCL.

However, the ${ }^{1} \mathrm{H}-\mathrm{NMR}$ spectrum for the obtained PLLA has a quadruplet with chemical shifts $(\delta)$ at 5.14, 5.17, 5.21 and $5.24 \mathrm{ppm}$ for the $\mathrm{CH}$ group, and a doublet at 1.59 and 1.62 for $\mathrm{CH}_{3}$ groups. It is noteworthy that the polymerization technique employed in this study is the solution polymerization and the molar ratio of monomer/catalyst is 1825 , which can lead to the formation of polymers of low molecular weight.

Table 4 presents the molecular weight $\left(\mathrm{M}_{\mathrm{n}}\right.$ and $\left.\mathrm{M}_{\mathrm{w}}\right)$ of PLLA and copolymers as well as polydispersity $\left(M_{w} / M_{n}\right)$. Except from sample $80 / 20\left(1,6.10^{3} \mathrm{~g} / \mathrm{mol}\right)$, the molecular weights ranged from $1,0.10^{4}$ to $1,3.10^{4} \mathrm{~g} / \mathrm{mol}$, showing that the increase $\mathrm{CL}$ concentration affects the molecular weight of copolymers, difficult to obtain poly(LLA-co-CL) with desired high molecular weight ${ }^{10,18}$. Samples 100/0, 95/5,

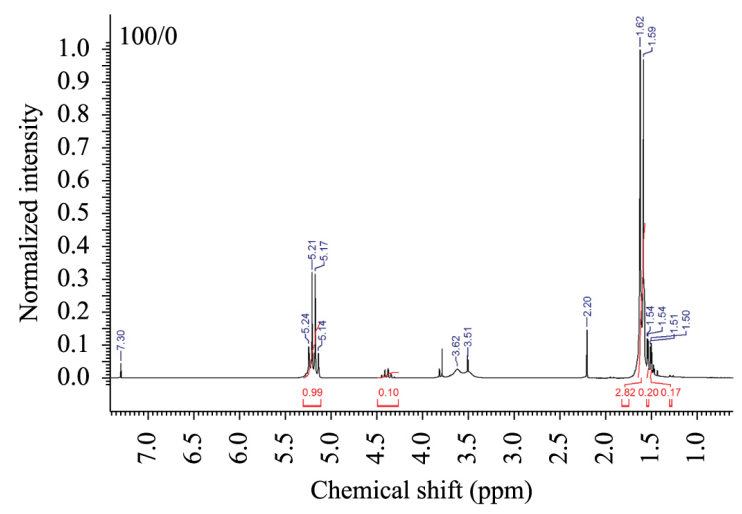

Figure 4. ${ }^{1} \mathrm{H}-\mathrm{NMR}$ spectrum of a sample of PLLA 100/0 obtained by solution polymerization after 24 hours of reaction at $120^{\circ} \mathrm{C}$.

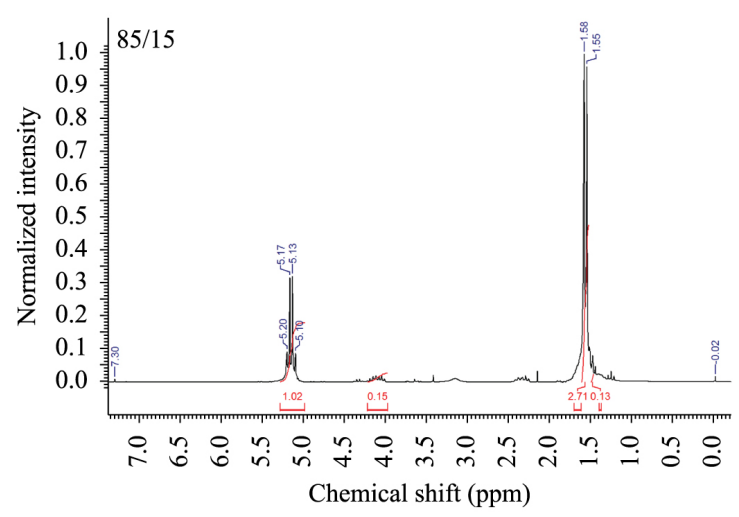

Figure 5. ${ }^{1} \mathrm{H}-\mathrm{NMR}$ spectrum of a sample of PLLA 85/15 obtained by solution polymerization after 24 hours of reaction at $120^{\circ} \mathrm{C}$.

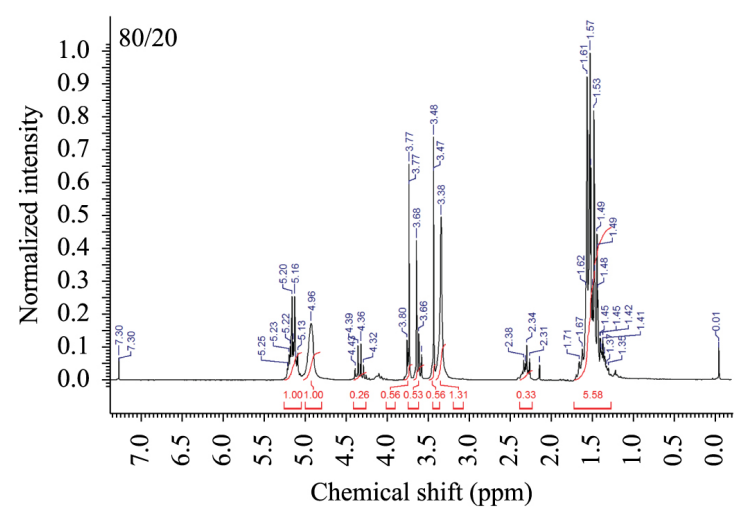

Figure 6. ${ }^{1} \mathrm{H}-\mathrm{NMR}$ spectrum of a PLLA 80/20 sample obtained by solution polymerization after 24 hours of reaction at $120^{\circ} \mathrm{C}$.

Table 4. PLLA and copolymers molecular weight $\left(\mathrm{M}_{\mathrm{n}}\right.$ and $\left.\mathrm{M}_{\mathrm{w}}\right)$, polydispersity $\left(\mathrm{M}_{\mathrm{w}} / \mathrm{M}_{\mathrm{n}}\right)$ obtained by GPC.

\begin{tabular}{cccc}
\hline Samples & $\mathbf{M}_{\mathbf{n}}$ & $\mathbf{M}_{\mathbf{w}}$ & $\mathbf{( M w / M n )}$ \\
\hline $100 / 0$ & $1.14 \times 10^{4}$ & $2.89 \times 10^{4}$ & 1.70 \\
$95 / 5$ & $1.01 \times 10^{4}$ & $1.60 \times 10^{4}$ & 1.58 \\
$90 / 10$ & $1.35 \times 10^{4}$ & $2.00 \times 10^{4}$ & 1.48 \\
$85 / 15$ & $1.21 \times 10^{4}$ & $2.14 \times 10^{4}$ & 1.76 \\
$80 / 20$ & $1.65 \times 10^{3}$ & $2.10 \times 10^{3}$ & 1.27 \\
\hline
\end{tabular}


90/10, showed a bimodal molecular weight distribution characteristic of PLLA synthesis, according to the literature. This behavior was not observed for samples 85/15, 80/20. Low molar ratio monomer / initiator, humidity and the presence of oxygen are factors that may have contributed to the reduction in molecular weight ${ }^{19,20}$.

\section{Conclusion}

The technique of polymerization, employing toluene as solvent at $120^{\circ} \mathrm{C}$, is effective for obtaining PLLA and the copolymer of PLLA-co-PCL, if CL mass fractions are above $20 \%$. These results were confirmed by ${ }^{13} \mathrm{C}$-NMR and ${ }^{1} \mathrm{H}-\mathrm{NMR}$ techniques, since the signals in chemical shifts related to CL units were identified only for the $80 / 20$ sample.

\section{References}

1. Oyama HTT, Cortella LRX, Rosa INS, Filho LER, Hui WS, Cestari IN, et al. Assessment of the biocompatibility of the PLLA-PLCL scaffold obtained by electrospinning. Procedia Engineering. 2015; 110:135-142. http://dx.doi.org/10.1016/j. proeng.2015.07.021.

2. Boua-In B, Chaiyut K and Ksapabutr N. Optoelectron. Advanced Materials. 2010; 4:1404.

3. Motta EAR and Duek AC. Síntese e caracterização do copolímero poli (L-co-D,L ácido láctico). Polímeros Ciência e Tecnologia. 2007; 17(2):123-129. http://dx.doi.org/10.1590/ S0104-14282007000200011.

4. Motta EAR and Duek AC. Síntese, caracterização e degradação "in vitro" do Poli(L-ácido láctico). Polímeros Ciência e Tecnologia. 2006; 16(1):26-32. http://dx.doi.org/10.1590/ S0104-14282006000100008.

5. Gowda RR and Chakraborty D. Environmentally benign process for bulk ring opening polymerization of lactones using iron and ruthenium chloride catalysts. Journal of Molecular Catalysis A Chemical. 2009; 301(1-2):84-92. http://dx.doi.org/10.1016/j. molcata.2008.11.010.

6. Shi D, Hua J, Zhang L and Chen M. Synthesis of bio-based poly(lactic acid-co-10-hydroxy decanoate) copolymers with high thermal stability and ductility. Polymers. 2015; 7(3):468-483. http://dx.doi.org/10.3390/polym7030468.

7. Monteiro MSDSDB, Cucinelli RP No, Santos ICS, Silva EOD and Tavares MIB. Inorganic-organic hybrids based on poly ( $\varepsilon$-Caprolactone) and silica oxide and characterization by relaxometry applying low-field NMR. Materials Research. 2012; 15(6):825-832. http://dx.doi.org/10.1590/S151614392012005000121 .

8. Peponi L, Navarro-Baena I, Báez JE, Kenny JM and MarcosFernández A. Effect of the molecular weight on the crystallinity of PCL-b-PLLA di-block copolymers. Polymer. 2012; 53(21):45614568. http://dx.doi.org/10.1016/j.polymer.2012.07.066.

9. Gowda RR and Chakraborty D. Zinc acetate as a catalyst for the bulk ring opening polymerization of cyclic esters and lactide. Journal of Molecular Catalysis A Chemical. 2010; 333(12):167-172. http://dx.doi.org/10.1016/j.molcata.2010.10.013.

10. Castro ML. Copolimeros estatisticos biodegradáveis de e-caprolactona e l,l-dilactídeo: síntese, caracterização e propriedades. [Thesis]. São Paulo: Escola Politécnica da Universidade de São Paulo; 2006.
This can be related to the fact that the monomers volatilize at temperatures below $120^{\circ} \mathrm{C}$, generating a dynamic equilibrium between the gas and liquid phases in the reaction system, and as the CL presents a volatilization temperature lower than that of the LLA, the former can be in greater amount in the vapor phase.

The ${ }^{13} \mathrm{C}$-NMR signal intensities of $\left(-\mathrm{CH}_{3}\right)$ and $\left(-\mathrm{CHCH}_{3}\right)$ groups of LLA units, and $\left(-\mathrm{CH}_{2}^{-}\right)$groups of $\mathrm{CL}$ units are lower than the values mentioned by other authors, which suggests that the full area of these peaks is also smaller and therefore the molecular weights of both PLLA and PLLA-co-PCL (80/20) are low. This fact may be associated with the solvent chose for the synthesis ${ }^{21}$. The present study shows that higher CL concentrations and smaller headspace can facilitate obtaining copolymers.

11. Odian G. Principles of polymerization. 3rd ed. New York: Wiley; 1991.

12. Qin Y, Liu S, Zhang Y, Yuan M, Li H and Yuan M. Effect of poly( $\varepsilon$-caprolactone-co-L-lactide) on thermal and functional properties of poly(L-lactide). International Journal of Biological Macromolecules. 2014; 70:327-333. http://dx.doi.org/10.1016/j. ijbiomac.2014.07.004. PMid:25020084.

13. Re GL, Benali S, Habibi Y, Raquez J-M and Dubois P. Stereocomplexed PLA nanocomposites: from in situ polymerization to materials properties. European Polymer Journal. 2014; 54:138-150. http://dx.doi.org/10.1016/j.eurpolymj.2014.03.004.

14. Torabinejad B, Mohammadi-Rovshandeh J, Davachi SM and Zamanian A. Synthesis and characterization of nanocomposite scaffolds based on triblock copolymer of L-lactide, $\varepsilon$-caprolactone and nano-hydroxyapatite for bone tissue engineering. Materials Science and Engineering C. 2014; 42:199-210. http://dx.doi. org/10.1016/j.msec.2014.05.003. PMid:25063111.

15. Roa JPB, Mano V, Faustino PB, Felix EB, Silva MESR and Souza JD Fo. Síntese e caracterização do copolímero poli(3hidroxibutirato-co-e-caprolactona) a partir de poli(3-hidroxibutirato) e poli(E-caprolactona). Polímeros. 2010; 20(3):221-226. http:// dx.doi.org/10.1590/S0104-14282010005000038.

16. Chen G-X, Kim H-S, Kim E-S and Yoon J-S. Synthesis of high-molecular-weight poly(l-lactic acid) through the direct condensation polymerization of 1-lactic acid in bulk state. European Polymer Journal. 2006; 42(2):468-472. http://dx.doi. org/10.1016/j.eurpolymj.2005.07.022.

17. Colwell JM. Synthesis of polycaprolactone polymers for bone tissue repair. Queensland: Queensland University of Tecnhology; 2006.

18. He A, Han CC and Yang G. Preparation and characterization of PLLA/P(CL-b-LLA) blends by an in situ ring-opening polymerization. Polymer. 2004; 45(24):8231-8237. http:// dx.doi.org/10.1016/j.polymer.2004.08.076.

19. Kricheldorf HR and Kreiser-Saunders I. Polylactones 49: Bu4Sn-initiated polymerizations of $\varepsilon$-caprolactone. Polymer. 2000; 41(11):3957-3963. http://dx.doi.org/10.1016/S00323861(99)00606-0.

20. Garlotta D. A literature review of poly(lactid acid). Journal of Polymer and Environment. 2002; 9(2):63-84. http://dx.doi. org/10.1023/A:1020200822435.

21. Nampoothiri KM, Nair NR and John RP. An overview of the recent developments in polylactide (PLA) research. Bioresource Technology. 2010; 101(22):8493-8501. http://dx.doi.org/10.1016/j. biortech.2010.05.092. PMid:20630747. 